\title{
PERANCANGAN SISTEM INFORMASI GEOGRAFIS PARIWISATA DAN RUTE ANGKUTAN UMUM BERBASIS WEB PADA DINAS KEBUDAYAAN DAN PARIWISATA KOTA SALATIGA
}

\author{
Michael Yudha Pratama Bagau $\left(^{1)}\right.$ dan Hanna Prillysca Chernovita $\left(^{2)}\right.$ \\ ${ }^{1,2}$ Sistem Informasi Universitas Kristen Satya Wacana \\ Jl.Diponegoro 52-60, Salatiga, 50711 \\ E-mail : mich.yuudz@gmail.com ${ }^{1}$, hanna.chernovita@uksw.edu ${ }^{2)}$
}

\begin{abstract}
ABSTRAK
Pesatnya perkembangan teknologi memudahkan manusia dalam mengakses sebuah informasi, salah satunya adalah informasi spasial. Sistem informasi Geografis (SIG) adalah sistem berbasis komputer yang dapat mentransformasi, memanipulasi, dan menganalisis data spasial, salah satunya dalam pengembangan pariwisata. Informasi mengenai pariwisata di suatu tempat atau kota dapat dengan mudah didapat dengan adanya sistem informasi pariwisata. Pariwisata dapat meningkatkan perekonomian di suatu daerah. Semakin banyak tempat wisata, dan semakin banyak wisatawan yang mengunjunginya, maka akan menambah pendapatan daerah tersebut serta meningkatkan kesejahteraan masyarakat di suatu daerah tertentu. Kota Salatiga memiliki beberapa lokasi wisata rekreasi sampai wisata kuliner, namun tidak banyak yang mengetahui lokasi dari tempat-tempat tersebut, sehingga perlu dibuat sebuah sistem informasi geografis pariwisata dan rute angkutan umum berbasis website agar mudah dioperasikan dimana pun dan kapan pun. Sistem informasi geografis pariwisata dan rute angkutan umum berbasis website ditujukan untuk wisatawan yang datang ke kota Salatiga agar dapat mengakses informasi pariwisata dan angkutan umum yang menuju ke lokasi wisata yang ada di kota Salatiga secara online dan lengkap dalam pemberian informasinya. Perancangan Sistem Informasi Geografis Pariwisata dan Angkutan Umum ini dimulai dengan menentukan ide atau gagasan, mengumpulkan data, membuat UML, dan membuat representasi visual dalam kode HTML yang dapat dibuka melalui browser sebagai Sistem Informasi Geografis berbasis Web.
\end{abstract}

Kata Kunci: Sistem Informasi Geografis, Pariwisata, Jalur Angkutan, UML, Web

\section{PENDAhuluan}

Salatiga adalah kota di Provinsi Jawa Tengah yang berbatasan sepenuhnya dengan Kabupaten Semarang. Salatiga terletak 49 kilometer di sebelah selatan Kota Semarang dan 52 kilometer di sebelah utara Kota Surakarta, serta berada di jalan negara yang menghubungkan antara Semarang dengan Surakarta. Secara morfologi, Salatiga berada di daerah cekungan kaki Gunung Merbabu dan gunung-gunung kecil, yaitu Gunung Telomoyo, Gunung Ungaran, Gunung Payung, dan Gunung Rong, membuat Salatiga memiliki pemandangan gunung di arah Selatan- Barat.

Terbentuknya Kota Salatiga memiliki sejarah panjang. Kota ini terletak di Jawa Tengah, dan dalam riwayat awalnya terdapat pada prasasti Plumpungan berangka tahun 750 M. Dalam Prasasti tercatat sebuah watak (wilayah setingkat desa pada era Kerajaan Medang) bernama watak I hamra yang berada di wanua (gabungan dari beberapa watak yang dipimpin oleh seorang rakai) bernama wanua I trigosthya. Wilayah wanua I trigosthya ini diyakini sebagai cikal bakal kota Salatiga saat ini, sehingga diyakini bahwa Salatiga sudah dihuni sejak 750 M. Pada perkembangannya, yakni tahun 1757, Salatiga menjadi tempat berlangsungnya perjanjian antara R.M. Said dengan Sunan Pakubuwono III dari Kasunanan Surakarta dengan VOC (Vereenigde Oost-Indische
Compagnie). Perjanjian itu dikenal dengan Perjanjian Salatiga (Anwar, 2019).

Selama kurun waktu 1917-1943, pariwisata di Salatiga yang berupa keindahan obyek alam dan rekreasi air ditopang oleh adanya pembangunan infrastruktur yang memudahkan akses jalan, penerangan, transportasi, akomodasi, dan lain-lainnya. Rekreasi yang paling ramai diminati oleh wisatawan adalah Kalitaman, Kopeng, Muncul, dan mata air Senjoyo (Izah, 2019).

Pada zaman penjajahan kolonial Belanda, kota salatiga di juluki sebagai de Schoonste Stad van Midden Java atau bisa di artikan sebagai kota terindah di Jawa Tengah (Wiratama, 2018). Selain sebagai kota yang indah kota Salatiga juga memiliki berbagai jenis potensi wisata seperti wisata alam, wisata budaya, wisata sejarang, dan wisata kuliner. Keberagaman jenis wisata di kota Salatiga tidak luput dari kesadaran dan kepedulian pemerintah dan masyarakat dalam mengelola dan memelihara berbagai obyek wisata yang ada.

Dampak kemajuan teknologi saat ini mengakibatkan segala jenis informasi dapat disajikan secara online. Salah satu contoh penyajian informasi secara online adalah melalui website, yang dapat diakses oleh siap saja yang terhubung dengan internet. Website atau biasa disingkat web adalah halaman informasi yang disediakan melalui jalur internet sehingga bisa diakses di seluruh dunia selama terkoneksi dengan jaringan internet (Yulianto, 
Wijaya, \& Rudianto, 2018). Dinas Kebudayaan dan Pariwisata kota Salatiga memiliki website resmi yang beralamatkan di http://disbudpar.salatiga.go.id. Website ini memiliki tiga menu utama, yaitu Beranda, Profil, dan Kontak. Menu Beranda atau menu utama di dalam website ini berisi informasi dan berita-berita mengenai kebudayaan dan pariwisata yang ada di kota Salatiga. Di menu Beranda ini terdapat juga kolom bagi pos-pos terbaru, arsip berita dan informasi yang ada di website ini dari tahun-ke tahun, dan juga pilihan kategori dari berita atau informasi yang ada di website ini. Terdapat kolom pencarian, yang dapat membantu kita untuk mencari berita atau informasi di dalam website ini dengan menuliskan kata kunci atau judul dari berita atau informasi yang akan kita cari. Dilihat dari berita dan informasi yang ada pada website ini, seluruhnya hanya mengenai kebudayaan, seperti berita pengiriman Duta Seni Salatiga, berita mengenai acara kebudayaan yang pernah berlangsung di kota Salatiga, pentas seni atau festival yang sedang di selenggarakan, dll. Berita atau informasi mengenai pariwisata di kota Salatiga masih belum ada di dalam website ini.

Menu kedua yang ada di dalam website ini adalah menu Profil. Di dalam menu Profil ini terdapat lima sub menu. Sub menu pertama adalah struktur organisasi, sub menu ini menampilkan gambar struktur organisasi dari pengurus Dinas Kebudayaan dan Pariwisata kota Salatiga. Sub menu kedua adalah dasar hukum, menu ini menampilkan undang-undang yang mengatur tentang Pemerintahan Daerah. Sub menu ke tiga adalah tugas pokok dan fungsi, sub menu ini menampilkan tugas pokok dari pengurus di Dinas Kebudayaan dan Pariwisata kota Salatiga. Sub menu ke empat adalah visi misi, dilihat dari namanya sub menu ini menampilkan visi misi kota Salatiga. Dan sub menu terakhir adalah sejarah, di dalam sub menu tidak terdapat apa-apa atau masih kosong. Dan menu terakhir yang ada di dalam website Dinas Kebudayaan dan Pariwisata kota Salatiga adalah menu Kontak. Di dalam menu ini menampilkan alamat dan email kantor Dinas Kebudayaan dan Pariwisata kota Salatiga.

Informasi mengenai pariwisata di kota Salatiga yang tercantum di dalam website ini masih belum ada. Dari berita dan informasi yang terdapat di dalam website ini hanya bertema kebudayaan. Menambahkan satu menu yang dapat dikhususkan sebagai menu pariwisata untuk website ini. Menu ini bisa diisi dengan informasi mengenai pariwisata dan jalur angkutan kota (angkutan) yang ada di kota Salatiga. Perancangan Sistem Informasi Geografis ini dapat dijadikan sebagai menu baru pada website Dinas Kebudayaan dan Pariwisata Kota Salatiga yang dikhususkan bagi pariwisata. Menu baru ini akan menampilkan visualisasi peta digital kota Salatiga beserta tempat-tempat wisata yang ada di kota Salatiga. Selain menampilkan peta lokawisata, menu ini juga dapat memberikan informasi mengenai tempat-tempat wisata di kota Salatiga, dan menunjukkan jalur angkutan sesuai nomor jalur yang dilalui bagi para wisatawan yang datang ke kota Salatiga. Berdasarkan uraian diatas, peneliti mengangkat judul "Perancangan Sistem Informasi Geografis Pariwisata dan Rute Angkutan Umum Berbasis Web Pada Dinas Kebudayaan Dan Pariwisata Kota Salatiga".

\section{RUANG LINGKUP}

Website milik Dinas Kebudayaan dan Pariwisata kota Salatiga tidak memberikan informasi mengenai pariwisata dan informasi rute angkutan yang ada di kota Salatiga. Oleh karena itu perlu adanya penambahan sistem informasi pariwisata dan rute angkutan umum pada web Dinas Kebudayaan dan Pariwisata kota Salatiga.

Rencana hasil yang didapat adalah sistem informasi geografis, yang diterapkan dengan peta digital yang memberikan informasi mengenai pariwisata, dan rute angkutan kota Salatiga.

\section{BAHAN DAN METODE}

Bagian ini menjelaskan teori yang berkaitan dengan topik, dan metode yang digunakan dalam penelitian, adalah sebagai berikut.

\subsection{Sistem Informasi Geografis Pariwisata dan Angkutan Umum}

Sistem Informasi Geografis atau disingkat SIG merupakan suatu sistem berbasis komputer yang digunakan untuk mengumpulkan, menyimpan, mengatur, mentransformasi, memanipulasi, dan menganalisis datadata geografis (Kumaat, Dr. Eng. Steven R. Sentinuwo, ST., MTI, \& Agustinus Jacobus, ST, M.Cs, 2016). Istilah geografi digunakan karena SIG dibangun berdasarkan pada geografi atau spasial. Objek ini mengarah pada spesifikasi lkasi dalam suatu space. SIG merupakan sistem komputer yang berbasis pada sistem informasi yang digunakan untuk memberikan bentuk digital dan analisis terhadap permukaan geografi bumi (Lucyana, 2016).

Pariwisata adalah salah satu yang dapat dikembangkan oleh bantuan SIG. Menurut Undang-undang no 10 tahun 2009 tentang Kepariwisataan, Pariwisata adalah "Berbagai macam kegiatan wisata dan didukung fasilitas serta layanan yang disediakan masyarakat setempat, sesama wisatawan, pemerintah, pemerintah daerah dan pengusaha". Sedangkan menurut WTO atau World Tourism Organization, Pariwisata adalah kegiatan manusia yang melakukan perjalanan ke dan tinggal di daerah tujuan di luar lingkungan kesehariannya. Secara Etymologis, kata "PARIWISATA" berasal dari bahasa sansekerta terdiri dari dua suku kata, yaitu "pari" dan "wisata". "Pari" berarti banyak, berkali-kali, berputarputar, lengkap, sedangkan "Wisata" berarti perjalanan, atau dapat pula diartikan bepergian (Firliana, Kasih, \& Suprapto, 2018). Terdapat 4 lokawisata yang ada di kota Salatiga, daftar dari tempat-tempat tersebut dapat dilihat pada tabel 1 . 
Tabel 1. daftar Lokasi Pariwisata di kota Salatiga dan sekitarnya.

\begin{tabular}{|c|c|c|}
\hline No & Nama & Alamat \\
\hline 1 & $\begin{array}{c}\text { D'Emmerick / Agrowisata } \\
\text { Salib Putih }\end{array}$ & $\begin{array}{c}\text { Jl. Hasanudin Km.4 } \\
\text { (Jalan Salatiga - Kopeng) }\end{array}$ \\
\hline 2 & Pemandian Kalitaman & $\begin{array}{c}\text { Jl. Kalitaman, } \\
\text { Kutowinangun Kidul, } \\
\text { Tingkir }\end{array}$ \\
\hline 3 & Prasasti Plumpungan & $\begin{array}{c}\text { Jl. Patimura No.35, } \\
\text { Kauman Kidul, Kec. } \\
\text { Sidorejo }\end{array}$ \\
\hline 4 & Atlantic Dreamland & $\begin{array}{c}\text { Jl. Soekarno Hatta Isep- } \\
\text { isep, Cebongan, Kec. } \\
\text { Argomulyo }\end{array}$ \\
\hline
\end{tabular}

Dalam perancangan sistem informasi geografis perlu untuk membuat pemodelan dengan bantuan Unified Modeling Language. Unified Modeling Language ( UML ) adalah Bahasa standar untuk membuat rancangan software. UML biasanya digunakan untuk menggambarkan dan membangun, dokumen artifak dari software intensive system (Sasmito, 2017). Dengan menggunakan UML dapat dibuat model untuk semua jenis aplikasi perangkat lunak. Aplikasi tersebut dapat berjalan pada perangkat keras, sistem operasi dan jaringan apapun, serta ditulis dalam bahasa pemrograman apapun. Tetapi karena UML juga menggunakan class dan operation dalam konsep dasarnya, maka ia lebih cocok untuk penulisan perangkat lunak dalam bahasabahasa berorientasi objek, seperti $\mathrm{C}++$, Java, atau VB.NET (Efendi, 2017).

Seperti bahasa-bahasa lainnya, UML mendefinisikan notasi dan syntax/ sematik. Notasi UML merupakan sekumpulan bentuk khusus untuk menggambarkan berbagai diagram perangkat lunak. Setiap bentuk memiliki makna tertentu, dan UML syntax mendefinisikan bagaimana bentuk-bentuk tersebut dapat dikombinasikan. Notasi UML terutama diturunkan dari 3 notasi yang telah ada sebelumnya: Grady Booch OOD (Object Oriented Design), Jim Rumbaugh OMT (Object Modeling Teknik), dan Ivar Jacobson OOSE (Object Oriented Software Engineering) (Anardani, 2019).

\subsection{Metode dan Tahapan Penelitian}

Penelitian dilakukan di Dinas Kebudayaan dan Pariwis ata kota Salatiga. Data yang didapat berupa data lokasi pariwisata, dan data jalur angkutan kota Salatiga. Pengumpulan data dilakukan dengan cara wawancara, dan berdiskusi dengan bapak Panji Hanief Gumilang, bagian Kasi Destinasidan Promosi Pariwisata Disbudpar Kota Salatiga, Dinas Kebudayaan dan Pariwisata kota Salatiga. Wawancara dan diskusi dilakukan untuk mendapatkan data lokawisata (peta pariwisata kota Salatiga 2016), dan data jalur angkutan kota Salatiga (peta trayek 2017). Data yang telah didapat diolah menggunakan ArcGIS menjadi peta digital. Data jalan angkutan kota Salatiga, dibagi berdasarkan jalur dari setiap nomor angkutan, yaitu dari nomor 1 hingga angkutan nomor 17 . Ke 17 jalur angkutan ditunjukan pada gambar 1 .

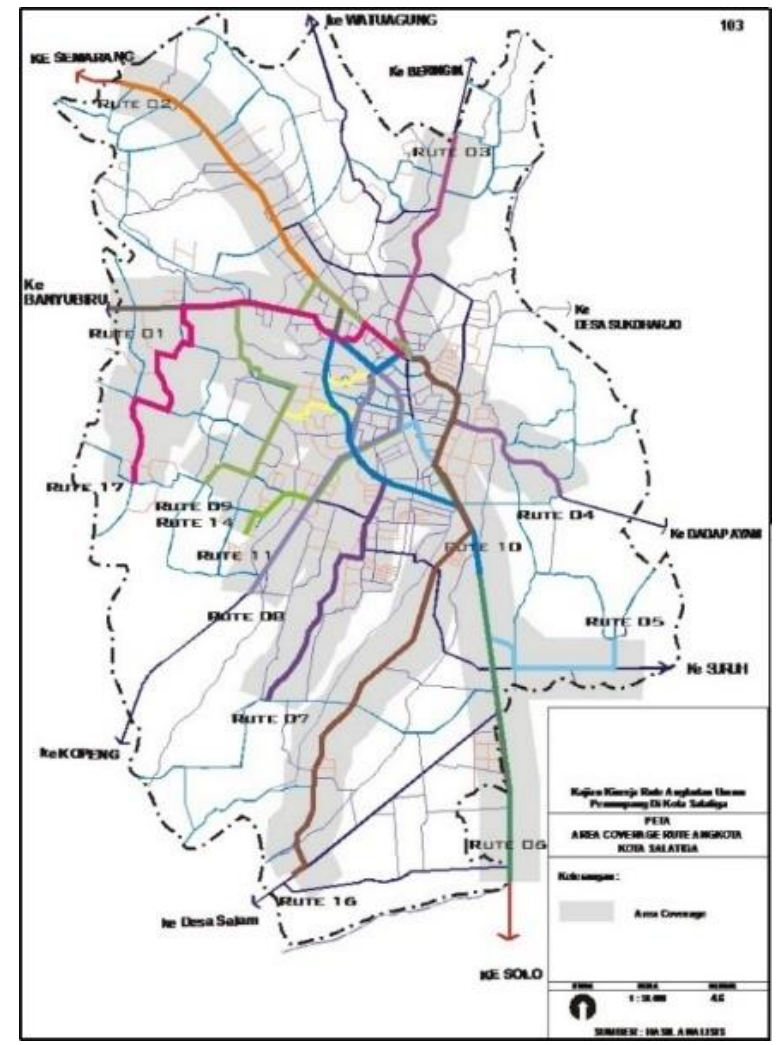

Gambar 1. Peta jalur angkutan kota Salatiga dengan warna yang dibedakan setiap jalurnya.

Sebelum melakukan coding, perlu untuk membuat UML dari sistem yang akan dibuat terlebih dahulu. UML yang dibuat adalah Use case diagram, Activity diagram, dan Class diagram. Untuk metode pembuatan Sistem Informasi Geografis Pariwisata, dan Jalur angkutan Kota Salatiga adalah metode waterfall. Metode Waterfall adalah metode yang melakukan pendekatan secara sistematis dan urut mulai dari level kebutuhan sistem lalu menuju ke tahap analisis, desain, coding, testing / verification, dan maintenance (Wijaya \& Astuti, 2019). Disebut dengan waterfall karena tahap demi tahap yang dilalui pada metode ini harus menunggu selesainya tahap sebelumnya. Secara umum tahapan pada model waterfall dapat dilihat pada gambar 2 .

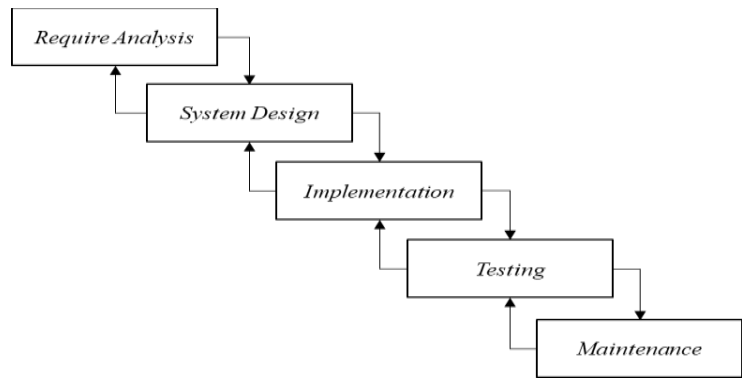

Gambar 2. Metode Waterfall 
Dalam metode waterfall terdapat 5 langkah, yaitu Require Analysis, System Design, implementation, testing, dan maintenance. Langkah pertama adalah Require Analysis, melakukan wawancara dan diskusi dengan pihak Dinas Kebudayaan dan Pariwisata kota Salatiga. Langkah kedua adalah System Design, membuat desain sistem dengan Unified Modeling Language ( UML ), yaitu sebuah tools atau alat yang dapat diandalkan dalam bidang pengembangan berbagai sistem yang berorientasi objek (Laia \& Ellbert, 2020). Penelitian ini dibatasi hanya sampai perancangan System Design dan tidak sampai ke tahap implementation, testing, dan maintenance. Langkah ketiga adalah Implementation, mulai menerjemahkan kedalam Bahasa pemograman. Langkah keempat adalah melakukan Testing, pengujian dari hasil Implementation untuk mengetahui design dan fungsi sudah sesuai atau belum. Dan langkat terakhir adalah Maintenance, melakukan pemeliharaan dan perbaikan terhadap kesalahan pada tahap Implementation (Sasmito, 2017). Hasilnya adalah Sistem Informasi Geografis Pariwisata dan Angkutan Umum berbasis web.

\section{PEMBAHASAN}

Dari data yang telah didapatkan, kota Salatiga memiliki 4 lokawisata sebagai tujuan, dan 17 jalur ankot, dan setiap jalur menggunakan nomor sebagai penanda tujuan dari angkot tersebut. Dari data yang telah didapat dibuatlah perancangan system dengan membuat UML, setiap proses yang dilakukan untuk memperoleh data yang akan diolah menjadi informasi akan dimodelkan dalam use case diagram. Setiap kegiatan dalam masingmasing proses digambarkan dalam activity diagram, use case diagram, dan class diagram (Fu'ad \& Gunawan, 2018). Dan Langkah selanjutnya menerapkan menjadi sebuah system informasi geografis.

\subsection{Perancangan Sistem}

Perancangan sistem dilakukan dengan membuat UML. Perancangan sistem betujuan untuk memberi gambaran dari program yang kita buat. User adalah pengguna yang dapat mengakses informasi pada sistem informasi geografis pariwisata, tetapi user tidak memperoleh hak untuk mengelola informasi yang ada pada sistem informasi geografis pariwisata. Admin adalah orang yang bertugas mengelola dan dapan mengakses informasi yang ada pada sistem informasi geografis pariwisata. Use case diagram menggambarkan tentang dasar pengelolaan Sistem Informasi Geografis pariwisata dan angkutan umum berbasis web pada Dinas Kebudayaan dan Pariwisata Kota Salatiga. Use case diagram ditunjukkan pada pada gambar 3 .

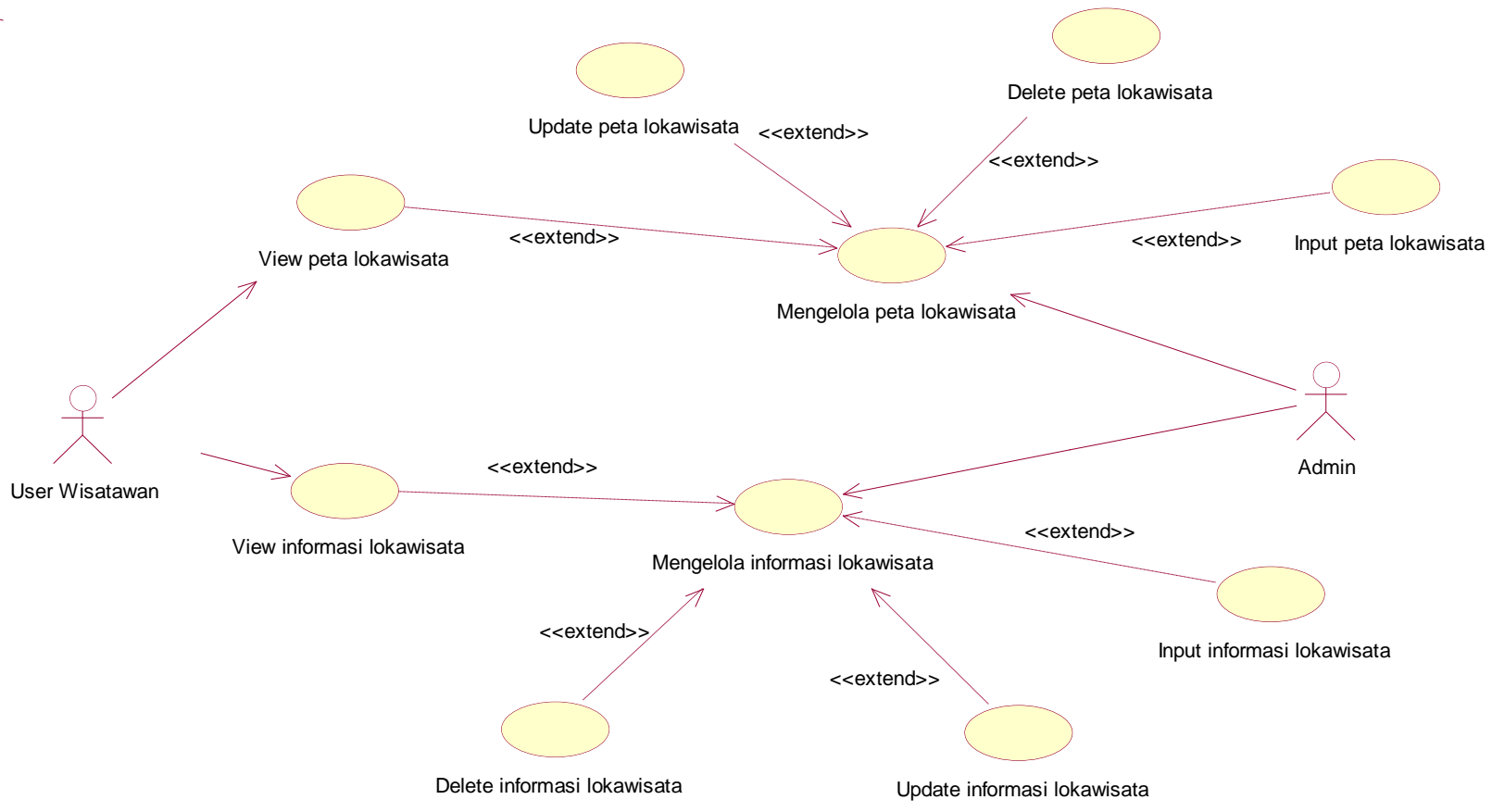

Gambar 3. Use case diagram

Use case diagram memiliki 2 aktor, yaitu wisatawan dan admin. Admin adalah aktor yang mengelola seluruh sistem. Admin dapat melihat, menghapus, menambahkan, dan memperbaharui peta lokawisata, dan informasi lokawisata. Wisatawan hanya memiliki fungsi melihat peta lokawisata, dan informasi lokawisata (Anwar, 2019).

Activity diagram adalah penggambaran aliran kerja dari menu user interface sistem informasi geografis pariwisata 
yang diakses oleh user. User dapat mengakses peta lokawisata dan melihat 3 jenis lokawisata, yaitu obyek wisata, kuliner, dan penginapan/hotel. Lokawisata yang dipilih oleh user dapat menampilkan data berupa, nama tempat lokawisata, alamat, dan nomor telepon. User juga dapat melihat jalur yang dilalui angkutan di kota Salatiga, dari jalur angkutan nomor 1 hingga jalur angkutan nomor 17. Activity diagram ditunjukkan pada gambar 4 .

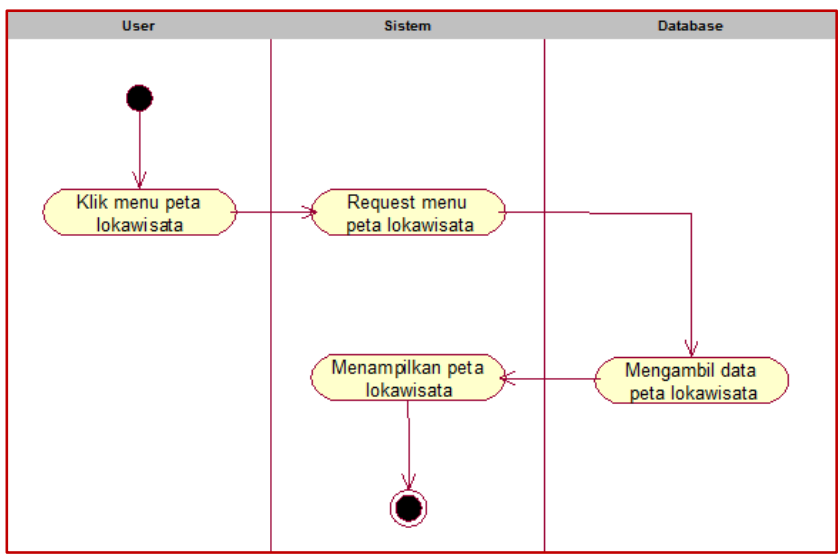

Gambar 4. Activity diagram

Aktivity diagram dimulai dari user yakni wisatawan menklik тепи peta lokawisata, sistem akan merespon untuk request ke database. Dari hasil request, database memberikan respon dengan menampilkan peta lokawisata, yang kemudian difungsikan untuk user. Aktivity diagram ditunjukan pada gambar 5 .

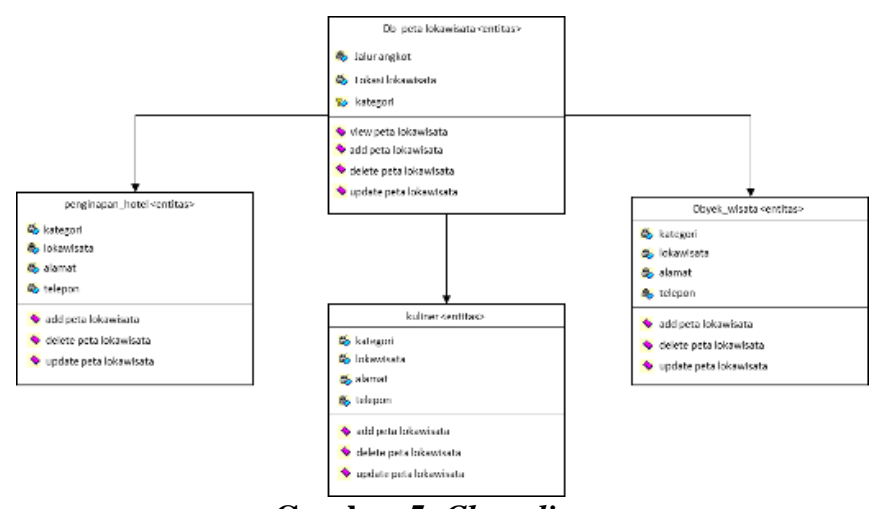

Gambar 5. Class diagram

Class diagram memiliki 1 database dan 3 entitas. Dalam database berisikan jalur angkutan, lokasi lokawisata, dan kategori. Dan controller pada database, yaitu view, add, delete, dan update. Entitas pertama adalah obyek wisata, berisikan kategori sebagai penghubung ke database, lokawisata, alamat, dan telepon. Controller pada entitas obyek wisata, yaitu add, delete, dan update. Entitas kedua adalah kuliner, berisikan kategori sebagai penghubung ke database, lokawisata, alamat, dan telepon. Controller pada entitas kuliner, yaitu add, delete, dan update. Entitas ketiga adalah penginapan hotel, berisikan kategori sebagai penghubung ke database, lokawisata, alamat, dan telepon. Controller pada penginapan hotel, yaitu add, delete, dan update.

\subsection{Implementasi Sistem}

Implementasi dari perancangan sistem informasi geografis pariwisata dan angkutan umum berbasis web pada Dinas Kebudayaan dan Pariwisata Kota Salatiga adalah peta digital yang diolah menggunakan RStudio. RStudio adalah Integrated Development Environment (IDE) untuk R, yaitu sebuah program komputasi statistika dan grafis (Lovelace, Nowosad, \& Muenchow, 2019). Dapat dilihat, untuk tempat lokawisata ditandai dengan simbol berwarna biru, dan peta jalur angkutan yang berupa simbol garis berwarna merah (lihat gambar 6).

Terlihat pada gambar 6 , bahwa terdapat menu pilihan pada kanan atas. Garis merah penunjuk jalur angkutan, dan simbol berwarna biru menunjukkan lokawisata.

Simbol lokawisata dibagi menjadi 3 jenis, yaitu Obyek Wisata, Hotel, dan Kuliner. Ketiga jenis lokawisata dapat dipilih salah satu untuk menampilkan lokawisata mana yang akan kita lihat. Jika telah memilih lokawisata mana yang akan kita lihat, akan muncul simbol berwarna biru yang menunjukkan lokasi dari lokawisata tersebut, dan juga kita klik simbol lokasi lokawisata akan muncul keterangan dari lokawisata tersebut. Informasi yang ditampilkan dalam kolom keterangan adalah nama lokawisata, alamat, nomor telepon, dan foto dari lokasi.

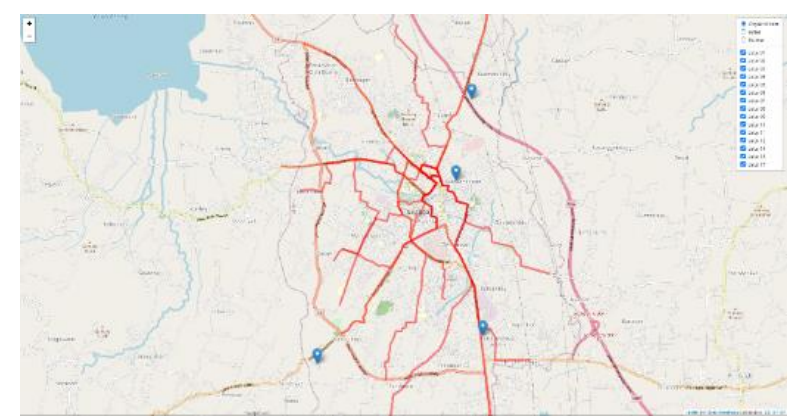

Gambar 6. Tampilan User interface

Gambar 7 menunjukkan tampilan obyek wisata setelah memilih menu "Obyek Wisata" pada kolom di kanan atas. Simbol biru menampilkan lokasi obyek wisata dan jika diklik akan menampilkan keterangan dari obyek wisata tersebut.

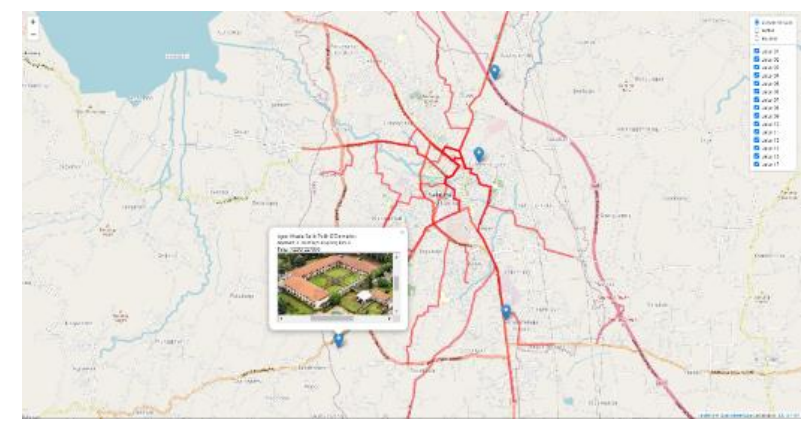




\section{Gambar 7. Tampilan obyek wisata setelah memilih} menu "Obyek Wisata" pada kolom di kanan atas.

Gambar 8 menunjukkan Tampilan lokasi hotel setelah memilih menu "Hotel" pada kolom di kanan atas. Simbol biru menampilkan lokasi hotel dan jika diklik akan menampilkan keterangan dari hotel tersebut.

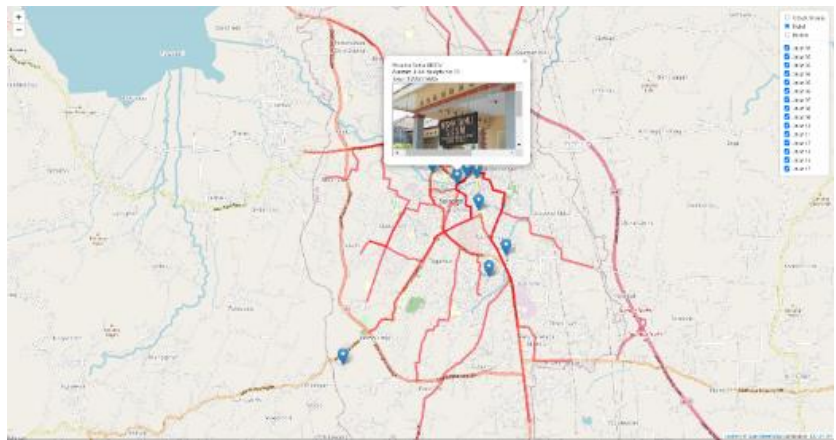

Gambar 8. Tampilan lokasi hotel setelah memilih menu "Hotel" pada kolom di kanan atas

Gambar 9 menunjukkan tampilan lokasi kuliner setelah memilih menu "Kuliner" pada kolom di kanan atas. Simbol biru menampilkan lokasi kuliner dan jika diklik akan menampilkan keterangan dari lokasi kuliner tersebut.

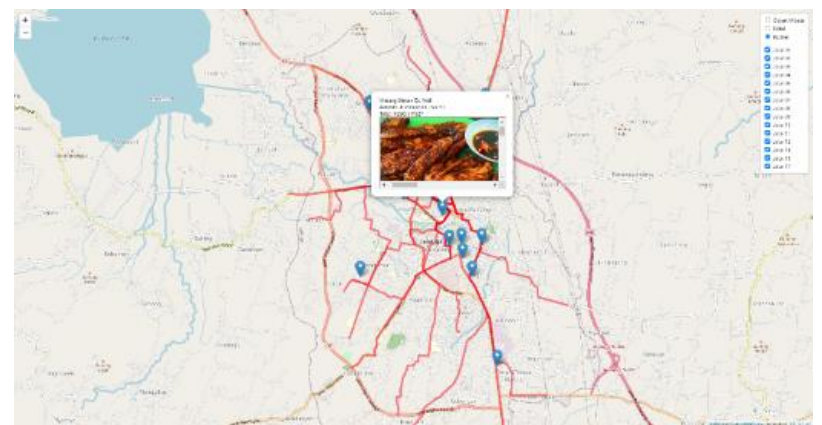

Gambar 9. Tampilan lokasi kuliner setelah memilih menu "Kuliner" pada kolom di kanan atas

Untuk jalur angkutan kota Salatiga ditampilkan dengan simbol garis berwarna merah. Jalur angkutan dapat kita pilih dari jalur nomor 1 hingga nomor 17. Jalur angkutan ditampilkan sesuai dengan jalur berapa yang kita pilih untuk ditampilkan, bisa satu-persatu atau langsung semua jalur. Tampilan peta jalur angkot dapat dilihat pada gambar 10 dan 11.

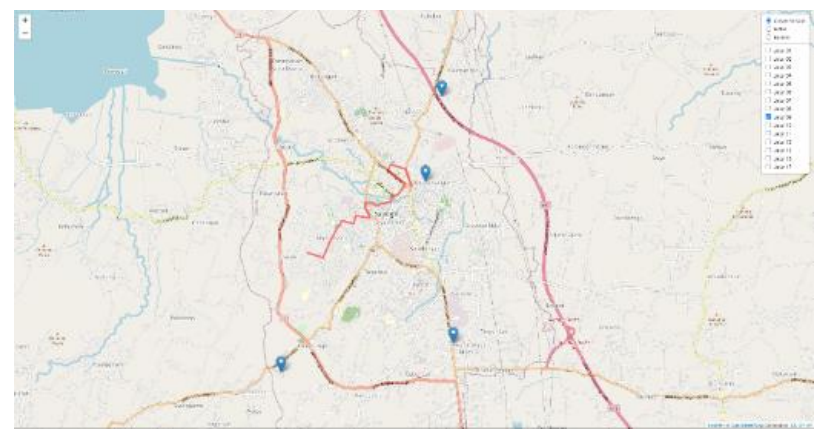

Gambar 10. Tampilan satu jalur angkutan jika user hanya memberi checklist hanya satu jalur saja

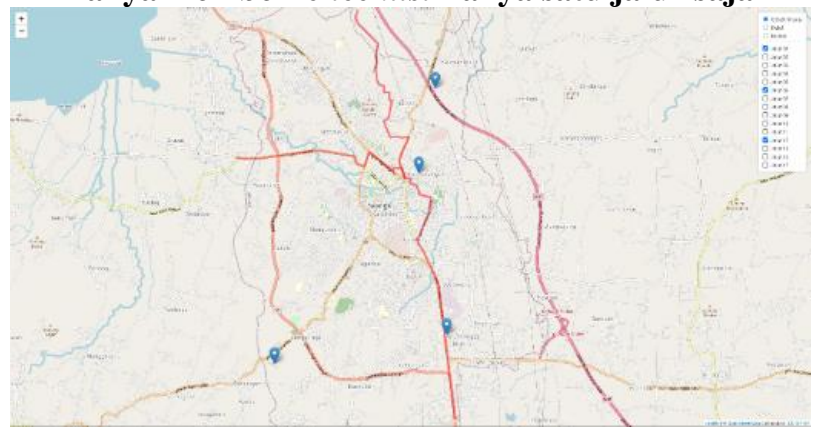

Gambar 11. Tampilan tiga atau lebih dari satu jalur angkutan.

Bisa dilihat pada gambar 10 dan 11 bahwa tidak hanya satu atau seluruh jalur yang diberi checklist, tetapi user dapat memilih jalur manapun yang akan ditampilkan.

\section{KESIMPULAN}

Dari hasil perancangan sistem informasi geografis pariwisata dan angkutan umum berbasis web pada Dinas Kebudayaan dan Pariwisata Kota Salatiga, telah menghasilkan peta digital. Peta digital tersebut dapat menampilkan informasi lokasi lokawisata, dan jalur angkutan di kota Salatiga. Untuk lokasi lokawisata terdapat keterangan mengenai lokawisata tersebut yang akan muncul jika kita menekan salah satu simbol berwarna biru pada user interface. User akan dimudahkan dalam mencari lokasi lokawisata yang akan dituju. Pada jalur angkutan, menampilkan jalur sesuai nomor angkutan. Jalur angkutan dapat dimunculkan sesuai keinginan user, bisa satu jalur, dua jalur atau langsung semua jalur untuk ditampilkan. Jalur angkutan juga memberikan informasi angkutan nomor berapa yang melintasi lokasi lokawisata yang akan dituju jika user perlu menggunakan transportasi umum.

\section{SARAN}

Saran yang diberikan peneliti dari penyusunan penelitian ini yaitu, banyak informasi yang dapat ditambahkan dalam keterangan mengenai lokasi lokawisata. Informasi yang mendukung supaya lebih informatif. Hasil dari peta digital selanjutnya dapat diterapkan pada website milik Dinas Kebudayaan dan Pariwisata Kota Salatiga, dan menjadi alat bantu dalam memberikan informasi mengenai tempattempat wisata di kota Salatiga bagi para wisatawan yang datang ke kota Salatiga. Wisatawan juga akan dimudahkan dengan adanya informasi mengenai jalur angkutan, dan memudahkan wisatawan untuk mengakses lokawisata tujuan.

Peta digital tersebut dapat diterapkan dikota lainnya. Peta digital ini memberikan informasi mengenai lokawisata di kota lainnya. Jalur angkutan juga dapat dikembangkan atau ditambahkan alat transportasi lain yang mengakses lokawisata pada kota tersebut. Bahkan dapat pula dikembangkan hingga keseluruh Indonesia. 


\section{DAFTAR PUSATAKA}

Anardani, S. 2019. Perancangan Sistem Berorientasi Objek Dengan Pemodelan UML(Unified Modeling Language). Madiun: UNIPMA Press.

Anwar, M. K. 2019. Rekontruksi Kota Kolonial Salatiga dan Kontribusi Teknologi Geographical Information System. Yogyakarta: Sasdaya Gadjah Mada Journal of Humanities.

Dinas Kebudayaan dan Pariwisata. 2016. Peta Pariwisata Kota Salatiga Tahun 2016. Salatiga: Dinas Kebudayaan dan Pariwisata Kota Salatiga.

Efendi, D. M. 2017. Sistem Informasi Geografis Rancangan Peta Digital Rute Angkutan Umum Kota Bandar Lampung. Kotabumi: STMIK DCC Kotabumi.

Firliana, R., Kasih, P., \& Suprapto, A. 2018. Pemanfaatan GIS Untuk Sistem Informasi Pariwisata. Nusantara of Enginering/Vol.3/No.1.

Fu'ad, T. D., \& Gunawan, W. 2018. Analisis Sistem Perancangan Penelitian Raport Siswa Berorientasi Objek UML (Unified Modeling Language) Di SMK Informatika Sukma Mandiri Cilegon. Banten: Jurnal Sains Dan Teknologi SAINTEK.

Izah, A. A. 2019. Perkembangan Pariwisata Di Salatiga (Studi Tentang Turisme Tahun 1917-1942). Surakarta: Universitas Sebelas Maret.

Kumaat, M., Dr. Eng. Steven R. Sentinuwo, ST., MTI, \& Agustinus Jacobus, ST, M.Cs. 2016. Rancang Bangun Sistem Informasi Geografis Jalur Angkutan Dalam Kota Di Kota Manado Berbasis Web. E-Journal Teknik Elektro dan Komputer vol. 5 no. 4.

Laia, F., \& E. H. 2020. Perancangan Aplikasi Futsal Sport Berbasis Android Di Kota Batam. (Journal of Computer Engineering System and Science Universitas Medan.

Lovelace, R., Nowosad, J., \& Muenchow, J. 2019. Geocomputation with R. Retrieved from https://geocompr.robinlovelace.net/index.html

Lucyana, R. 2016. Sistem Informasi Geografis Untuk Pemetaan Pariwisata Kabupaten Pesisir Barat Berbasis Web. Lampung: Fakultas Matematika dan ilmu Pengetahuan Alam Universitas Lampung.

Sasmito, G. W. 2017. Penerapan Metode Waterfall Pada Desain Sistem Informasi Geografis Industri Kabupaten Tegal. Jurnal Informatika:Jurnal Pengembangan IT (JPIT), Vol. 2, No. 1.

Wijaya, Y. D., \& Astuti, M. W. 2019. Sistem Informasi Penjualan Tiket Wisata Berbasis Web Menggunakan Metode Waterfall. Madiun: Seminar Nasional Teknologi Informasi Dan Komunikasi SENATIK.

Wiratama, D. A. 2018. PERANCANGAN IDENTITAS VISUAL KOTA SALATIGA SEBAGAI KOTA MULTIKULTUR DAN TOLERAN. Yogyakarta: ARS: JURNAL SENI RUPA DAN DESAIN.

Yulianto, I., Wijaya, A. F., \& Rudianto, C. 2018. Perancangan Sistem Informasi Pariwisata Kota Salatiga Berbasis Web. Salatiga: SESINDO. 